\title{
Peran dan Fungsi Litbang dalam Mendukung Sistem Inovasi Daerah Provinsi Jambi \\ (Role And Function Of Research And Depelovment Board To Provide SIDa In Jambi Provincial)
}

\author{
Sayid Syekh \\ Fakultas Ekonomi Universitas Batanghari Jambi \\ Email: saiyid.syekh1959@gmail.com
}

\begin{abstract}
The purpose of development is to create a prosperous society. This goal is inseparable from the role of Research and Depelovment Board in the development process. This research raises the issue of the role of the Balitbangda and the strengthening of the Regional Innovation System (SIDa) of Jambi Province. Data is collected by interview, observation and documentation. Then the data is analyzed using the triungulation method. The result is the Balitbangda is the secretariat for strengthening the Regional Innovation System of Jambi Province. The steps taken in the formation of the Coordination Team are by establishing the Jambi Province Regional Innovation System Socialization Team and conducting socialization. collaboration with the research institutions and Universities. Cooperating with industry. Strengthening the Regional Innovation System is realized will not run smoothly without close coordination between related parties, both those under the coordination of the government and private institutions and universities / research institutions. The Balitbangda's support in strengthening the Regional Innovation System (SIDa) of Jambi Province is by implementing Kelitbangan based on the needs of the industry and the community.
\end{abstract}

Keywords:

Role, Synergy, Research and Depelovment, SIDa

\section{PENDAHULUAN}

Tujuan pembangunan adalah bagaimana meningkatkan kesejahteraan masyarakatnya. Sejak awal dibentuk, Provinsi Jambi yang hanya memilki 4 kabupaten sampai saat ini sudah memiliki 9 kabupaten dan 2 kota, aktifitas pembangunan terus dilakukan. Tujuan dibentuknya Provinsi Jambi dan dibentuknya beberapa kabupaten dan kota adalah sesuai dengan tujuan nasional sebagaimana yang diamanatkan dalam Pembukaan UUD 1945 yaitu pentingnya upaya mewujudkan kesejahteraan rakyat dan kemajuan seluruh wilayah secara merata. Dalam Undang-Undang Dasar 1945 disebutkan bahwa pemerintahan daerah mengatur dan mengurus sendiri urusan pemerintahan menurut asas otonomi dan tugas pembantuan, Tujuannya adalah untuk mempercepat terwujudnya kesejahteraan masyarakat melalui peningkatan pelayanan, pemberdayaan dan peran serta masyarakat, serta peningkatan daya saing daerah dengan memperhatikan prinsip demokrasi, pemerataan, keadilan, keistimewaan dan kekhususan suatu daerah dalam sistem Negara Kesatuan Republik Indonesia.

Untuk mewujudkan kesejahteraan masyarakat tersebut, Pemerintah Daerah diberi kewenangan untuk mengurus daerahnya masingmasing berdasarkan keinginan dan potensi daerah yang mereka miliki (UU No 23 Th 2014). Kebijakan ini menuntut daerah mampu untuk mengolah potensi-potensi daerah dengan penggunaan teknologi, dengan tujuan mendapatkan nilai tambah (added value).
Berdasarkan Peraturan Bersama Menteri Riset dan Teknologi dan Menteri Dalam Negeri No 03 dan 36 Tahun 2012, tentang Penguatan Sistem Inovasi Daerah, menuntut adanya Tim Koordinasi Penguatan Sistem Inovasi Daerah (SIDa) di setiap Provinsi dan Kabupaten/Kota. Sistem Inovasi Daerah yang selanjutnya disingkat SIDa adalah keseluruhan proses dalam satu sistem untuk menumbuhkembangkan inovasi yang dilakukan antar institusi pemerintah, pemerintahan daerah, lembaga kelitbangan, lembaga pendidikan, lembaga penunjang inovasi, dunia usaha, dan masyarakat di daerah.

Perber tersebut kemudian menunjuk Badan Penelitian dan Pengembangan Daerah (BPPD) sebagai institusi yang bertugas mengkoordinir Tim Penguatan Sistem Inovasi Daerah di Provinsi/Kabupaten/Kota.

Adapun keanggotaannya adalah institusi pemerintah, lembaga kelitbangan, lembaga pendidikan, lembaga penunjang inovasi, dunia usaha, dan organisasi kemasyarakatan di daerah (Pasal 15 Perber Menristek dan Mendagri No 03 dan 36 Th 2012, atau disebut dengan Triplehelix)

Tujuan dibentuknya tim Sistem Inovasi Daerah (SIDa) adalah untuk mensinergikan semua stakeholders terkait dalam membuat roadmap pengembangan potensi daerah di Provinsi dan Kabupaten/Kota dan menjalankannya berdasarkan tugas pokok masing-masing institusi.

Oleh karena itu, perlu diteliti sistem kerja Balitbangda dalam usaha mengkoordinir Tim Sistem Inovasi Daerah Provinsi Jambi dan 
menetapkan produk unggulan yang dikembangkan.

\section{METODE PENELITIAN}

Kajian ini dilakukan melalui pengumpulan data dengan cara wawancara, observasi, dan data sekunder. Wawancara dilakukan dengan anggota Tim SIDa Provins Jambi yang dipilih secara purpossive sampling, Kepala Balitbangda Provinsi Jambi, Bidang Inovtek, ketua tim pelaksana harian SIDa Provinsi Jambi dan anggota tim SIDa. Observasi dilakukan dengan mengikutserta pertemuan dan kegiatan Tim SIDa Provinsi Jambi. Data sekunder diperoleh melalui mempelajari laporan dan buku SIDa Provinsi Jambi.

Data dianalisis dengan metode triungilasi data, dimana antara satu data dengan data lainnya dikonfrontasikan dan disimpulkan.

\section{HASIL DAN PEMBAHASAN}

Langkah dan usaha Balitbangda Provinsi Jambi membentuk Tim Koordinasi Sistem Inovasi Daerah Provinsi Jambi

Berdasarkan Peraturan Bersama Menter Ristek dan Menteri Dalam Negeri RI Nomor 03 dan 36 Tahun 2012, pada pasal 34 menempatkan Balitbangda sebagai sekretariat penguatan Sistem Inovasi Daerah. Secara otomatis Balitbangda Provinsi Jambi adalah sekretariat Sistem Inovasi Daerah Provinsi Jambi.

Sebagaimana konsep Sistem Inovasi Daerah, bahwa Tim Penguatan SIDa adalah terdiri dari kaum akademisi, dunia usaha dan pemerintah. Untuk menyatukan ketiga unsur ini adalah sangat susah, karena antara ketiganya unsur ini sering bertolak belakang dan mempertahankan ego masing-masing.

Oleh karena itu, Balitbangda turun sebagai pelopor untuk mendudukkan ketiga unsur tersebut. Adapun langkah-langkah yang ditempuh adalah sebagai berikut:

a. Membentuk Tim Sosialisasi Sistem Inovasi Daerah Provinsi Jambi dan melaksanakan sosialisasi.

b. Melakukan kerjasama Kelitbangan dengan lembaga Litbang dan Perguruan Tinggi.

c. Melakukan kerjasama dengan industri.

\section{Membentuk Tim Sosialisasi Sistem Inovasi Daerah Provinsi Jambi dan melaksanakan sosialisasi.}

Langkah pertama usaha pembentukan Tim Sistem Inovasi Daerah Provinsi Jambi adalah dengan cara melakukan kunjungan ke setiap OPD di lingkup Pemerintah Provinsi Jambi dan OPD di Kabupaten/Kota dalam Provinsi Jambi, dengan tujuan memperkenalkan Peraturan Bersama Menristek dan Mendagri Nomor 03 dan 36 Tahun 2012, tentang makna dan pentingnya kebijakan tersebut bagi peningkatan kesejahteraan masyarakat dengan cara pengembangan potensi daerah dengan sentuhan iptek. Kabid Inovtek (23/05/2018) mengungkapkan bahwa;

"program pertama usaha pembentukan Tim Koordinasi Sistem Inovasi Daerah (SIDa) Provinsi Jambi adalah dengan melakukan sosialisasi ke OPD terkait seperti Dinas Perkebunan, Perdagangan, Koperasi, Pariwisata, PU dan lainnya. Selain itu, mengunjungi Perguruan Tinggi Negeri ataupun swasta yang ada di Provinsi Jambi, seperti Universitas Jambi, Universitas Batanghari dan Politeknik Jambi. Disamping itu juga, tim sosialisasi melakukan sosialisasi ke seluruh Kabupaten/Kota dalam Provinsi Jambi."

Dengan melaksanakan sosialisasi ke seluruh stakeholders terkait diharapkan mereka dapat mememahami dan mengerti akan pentingnya konsep Sistem Inovasi Daerah (SIDa) dalam pengembangan produk daerah dalam rangka meningkatkan nilai tambah produk masyarakat.

\section{Melakukan kerjasama Kelitbangan dengan lembaga Litbang dan Perguruan Tinggi.}

Balitbangda Provinsi Jambi melaksanakan kerjasama Kelitbangan dengan Universitas Jambi, Politeknik dan BPTP dalam usaha meningkatkan kualitas produk daerah di Provinsi Jambi. Dengan kerjasama ini, penelitian yang dilaksanakan oleh Perguruan Tinggi dan BPTP dapat dijadikan dasar akademis pengembangan produk daerah, sementara Politeknik dapat melakukan rekayasa teknologi bagi mempermudah pengolahan produk daerah. Kepala Ketua LP2M Universitas Jambi (25/05/2018) menerangkan bahwa;

"para peneliti UNJA di bawah naungan LP2M melakukan kerjasama dengan Balitbangda di bidang penelitian dan pengembangan produk daerah, dalam rangka meningkatkan nilai tambah hasil produk masyarakat".

Kerjasama tersebut dikuatkan dengan Memorendum of Understanding (MoU) antara kedua beleh pihak (MoU UNJA dan Balitbangda Nomor 02-2014). Dengan kerjasama ini, konsep dan strategi peningkatan hasil produk masyarakat dapat tercapai dengan baik.

\section{Melakukan kerjasama dengan industri.}

Dalam konsep Triplehelix, sinergitas dalam bekerja sangat diutamakan. Dalam program penguatan Sistem Inovasi Daerah (SIDa), sinergitas yang diperlukan adalah saling 
keterkaitan kerja mencapai satu tujuan. Balitbangda Provinsi Jambi sebagai institusi penelitian pada pemerintah daerah menjadi koordinator kegiatan penelitian dan pengembangan yang ada di lingkup Provinsi Jambi.

Oleh karena itu, untuk teraplikasinya hasil penelitian oleh pihak pengusaha atau industri perlu dilakukan kerjasama. Dimana program Kelitbangan yang dilaksanakan oleh pihak Balitbangda bersama dengan lembaga penelitian lainnya harus berdasarkan kebutuhan pihak pengusaha atau industri. Sehingga hasil Kelitbangan yang dilaksanakan oleh Balitbangda bersama lembaga litbang lainnya termanfaat atau dapat digunakan untuk meningkatkan kesejahteraan masyarakat.

Kabid Inovtek

$(23 / 05 / 2018)$

mengungkapkan bahwa;

\begin{abstract}
"pihak Balitbangda telah melakukan kerjasama dengan industri Kopi Paman, guna melakukan pendampingan dalam usaha meningkatkan produk kopi masyarakat Jambi".
\end{abstract}

Kopi Paman sebagai salah satu industri kopi di Jambi, harus didampingi agar mereka dapat memanfaatkan atau menggunakan kopi masyarakat Jambi dalam industri mereka. Pendampingan tersebut bertujuan untuk menyatukan pola pikir antara kebutuhan industri dengan usaha masyarakat.

\section{Dukungan Balitbangda dalam penguatan Sistem Inovasi Daerah (SIDa) Daerah Provinsi Jambi.}

Penguatan Sistem inovasi daerah di Provinsi Jambi diharapkan mampu mendongkrak nilai tambah produk unggulan yang ada di daerah ini seperi karet, pinang, resam dan lainlain. Tuntutan untuk meningkatkan nilai tambah tersebut semakin tinggi karena Jambi harus bersaing dengan daerah lain untuk berebut pasar domestik maupun internasional. Jika Provinsi Jambi masih mengekspor produk tersebut dalam kedaan mentah, maka daerah atau Negara lainlah yang menikmati keuntungan terbesar dari produk tersebut sementara masyarakan di Jambi hanya memperoleh bagian keuntungan yang kecil dan lambat laun menguras kekayaan yang ada di daerah ini.

Penguatan Sistem Inovasi Daerah disadari tidak akan berjalan mulus tanpa adanya koordinasi yang erat antara pihak terkait, baik yang berada di bawah koordinasi pemerintah maupun lembaga swasta dan pihak perguruan tinggi/lembaga litbang. Upaya membangun kerjasama tersebut merupakan salah satu poin terpenting dari penguatan SIDa tersebut.
Strategi yang diambil Balitbangda untuk penentuan judul kajian/penelitian :

1. Menata sistem penentuan topik Litbang yang akan dilaksanakan guna memperoleh kegiatan Litbang prioritas secara lebih selektif.

2. Meningkatkan aktivitas kajian ilmiah dan sosialisasi hasil Litbang sebagai wahana untuk menumbuh kembangkan jejaring kerjasama dan koordinasi kegiatan Litbang.

3. Mendorong kerjasama dengan instansi terkait terutama dalam usaha pemecahan permasalahan (problem solving) melalui pemanfaatan hasil Litbang.

4. Mengusulkan penambahan kuantitas tenaga fungsional peneliti pada Balitbangda Provinsi Jambi.

Kebijakan yang di lakukan Balitbangda dalam menganalisis isu aktual yang terjadi :

a) Melaksanakan kegiatan Litbang yang berkaitan dengan isu-isu aktual program strategis pemerintah daerah.

b) Membangun jejaring kerjasama kelembagaan dengan stakeholders terkait untuk meningkatkan pemahaman dan menciptakan sinergi dalam kegiatan Litbang.

c) Meningkatkan kapasitas tenaga fungsional peneliti dan pejabatstruktural dalam rangka mendukung kegiatan Litbang di daerah

\section{SIMPULAN}

1. Balitbangda adalah sekretriat penguatan Sistem Inovasi Daerah Provinsi Jambi. Adapun langkah-langkah yang ditempuh dalam pembentukan Tim Koordinasi adalah dengan cara membentuk Tim Sosialisasi Sistem Inovasi Daerah Provinsi Jambi dan melaksanakan sosialisasi. Melakukan kerjasama Kelitbangan dengan lembaga Litbang dan Perguruan Tinggi. Melakukan kerjasama dengan industri. Penguatan Sistem Inovasi Daerah disadari tidak akan berjalan mulus tanpa adanya koordinasi yang erat antara pihak terkait, baik yang berada di bawah koordinasi pemerintah maupun lembaga swasta dan pihak perguruan tinggi/lembaga litbang.

2. Dukungan Balitbangda dalam penguatan Sistem Inovasi Daerah (SIDa) Daerah Provinsi Jambi adalah dengan cara melaksanakan Kelitbangan berdasarkan kebutuhan pihak industri dan masyarakat.

\section{DAFTAR PUSTAKA}

Undang-undang Nomor 23 Tahun 2014

Peraturan Bersama Menteri Ristek dan Mendagri Nomor 3 dan 36 tahun 2012.

Balitbangda Provinsi Jambi, 2012, Laporan Pelaksanaan Pemerintah Daerah 
Balitbangda,2013. Laporan Pelaksanaan Pemerintah Daerah Provinsi Jambi

Balitbangda, 2014. Laporan Pelaksanaan Pemerintah Daerah Provinsi Jambi

Balitbangda, 2015. Laporan Pelaksanaan Pemerintah Daerah

Balitbangda Provinsi Jambi, 2016. Laporan Pelaksanaan Pemerintah Daerah

Balitbangda Provinsi Jambi, 2017. Laporan

Pelaksanaan Pemerintah Daerah

Balitbangda Provinsi Jambi 